\title{
AN ATHEISTIC DEFENCE OF CHRISTIAN SCIENCE
}

\section{BRADLEY MONTON}

\section{University of Colorado Boulder}

Should the Christian community engage in Christian science - doing science starting from the standpoint of the Christian evidence base? Plantinga asks this question, and I argue that the answer is 'yes'. Moreover, this is an answer that both Christians and atheists can agree upon. Scientific progress should not be shackled by methodological naturalism; instead we need an ecumenical approach to science, which will allow for various high-level research programmes to count as science (including Christian science). If one does science by giving scientific arguments for or against such research programmes, one will fulfil the goal of having science be objective, open, and universal, not constrained by a methodology that favours the naturalistic worldview.

\section{CONCORD AND CONFLICT}

I'm tempted to say: there is superficial concord but deep conflict between Plantinga and me - we agree on certain methodological claims about science, and disagree about whether God exists. But in fact, I want to argue in this paper that the concord is more than superficial - our similar views about how Christians should do science, given what they believe as Christians, are non-trivial - and it is the point of this paper to elaborate on that. But still, the conflict should be acknowledged, so for starters let's turn there.

Plantinga is a Christian and I am an atheist, and we both understand Christianity, properly construed, to be a robust metaphysical position. One reason Plantinga endorses Christianity is that he believes he has a sensus divinitatis, a cognitive faculty that allows him to perceive God's presence and properties and demands. But Plantinga holds that the sensus divinitatis of contemporary humans is corrupted by sin. And as an atheist, my sensus divinitatis may well be more corrupted 
than Plantinga's (though not necessarily through any fault of my own, thankfully). ${ }^{1}$

I reject this account, of course. Why am I an atheist? I used to maintain that the main reason was the problem of evil, but I no longer maintain that. Part of the reason I don't is that Plantinga has famously provided a variety of promising responses to the problem of evil. ${ }^{2}$ But more importantly, I've recognized that I wouldn't believe in God even if there were no evil. Imagine a world like this one, but without evil - it is full of happy bunnies and awe-inspiring rainbows and well-behaving people. Still, in such a world I wouldn't see any positive reason to believe in God - I wouldn't believe in God, because of the lack of evidence. (This is not meant to be a rejection of reformed epistemology; just a statement of why I don't believe.)

This is why I'm interested in the project of finding evidence for the existence of God - I want to know whether I'm wrong; I want to know whether the evidence is really there. I'm sceptical of the sensus divinitatis, the historical evidence is inconclusive at best, and the ostensible deliverances of revelation are wildly contradictory. But science - science provides a potential means of providing the sort of objective evidence for the truth of Christianity that I seek.

So can the Christian do it? Can the Christian appeal to science to provide evidence to atheists like me of the truth of Christianity? I'll start by looking at a popular objection to this project, based on the misguided claim that the methodology of science excludes supernatural hypotheses. Then I'll talk about how to understand science as involving competing high-level research programmes, including the scientific research program based on the doctrines of Christianity. Despite my willingness to include a Christian research programme as part of science, there are some restrictions I want to place on scientific methodology; I'll outline those restrictions next. Finally, I'll remind the reader that I think this project of looking to science to support Christianity - intriguing and promising as it is - will ultimately be unsuccessful.

${ }^{1}$ Alvin Plantinga, Warranted Christian Belief(Oxford: Oxford University Press, 2000), p. 214, note 22: 'It is no part of this model to say that damage to the sensus divinitatis on the part of a person is due to sin on the part of the same person.'

${ }_{2}$ Alvin Plantinga, The Nature of Necessity (Oxford: Oxford University Press, 1974), Chapter 9; Alvin Plantinga, 'Supralapsarianism, or "O Felix Culpa” in Peter van Inwagen (ed.), Christian Faith and the Problem of Evil (Grand Rapids: Wm. B. Eerdmans Publishing Co., 2004), pp. 1-25. 


\section{AGAINST METHODOLOGICAL NATURALISM}

How is science currently practiced? Many people attribute to current science a commitment to methodological naturalism. Plantinga is one of these people; he says that 'Contemporary science, science as it is currently practiced, is characterised by methodological naturalism, either weak or strong.' Weak methodological naturalism holds that a scientific evidence base will not include the proposition that there is such a person as God; strong methodological naturalism will add the denial that there is a God to the scientific evidence base. ${ }^{3}$ When scientists follow methodological naturalism, they sometimes will, unsurprisingly, produce theories incompatible with Christian belief. Plantinga calls the sort of science that follows methodological naturalism, and produces theories incompatible with Christian belief, 'Simonian science'.

Plantinga correctly points out that when Simonian science reaches conclusions incompatible with the tenets of Christianity, that does not automatically constitute a defeater for the Christian tenets with which those conclusions are incompatible. The reason that does not automatically constitute a defeater is that Simonian science is describing how things look from what, by Christian lights, is a restricted evidence base. The restricted evidence base does not include the evidence that Christians take to support Christianity - if scientists took that evidence into account, then they would no longer be following methodological naturalism.

Plantinga then asks some important questions. In addition to understanding phenomena from the perspective of Simonian science,

shouldn't the Christian also want to know how the phenomena in question look from the standpoint of the Christian evidence base? ... Shouldn't the Christian community engage in Christian science - not in the sense of following Mary Baker Eddy, but in the sense of engaging in empirical study unconstrained by methodological naturalism? ${ }^{4}$

Plantinga says that these are 'excellent questions', but addressing them in his book would take us 'too far from the main line of argument'.

${ }^{3}$ Alvin Plantinga, Where the Conflict Really Lies (New York: Oxford University Press, 2011), p. 174. Plantinga's definitions of weak and strong methodological naturalism are a bit more complicated than I've stated, and it's not clear to me that as stated they capture what he's trying to capture, but readers of Plantinga (and this paper) can get the basic idea. Plantinga likes to occasionally leave projects to readers as asides, so in that spirit I'll leave this one, of working out the correct definitions of weak and strong methodological naturalism.

${ }^{4}$ Alvin Plantinga, Where the Conflict Really Lies, p. 190. 
Here I have a minor note of disagreement with Plantinga. If Plantinga wants to argue that there is concord between Christian belief and science, then these excellent questions are not too far from the main line of argument. The reason is that, if science is committed to methodological naturalism, one will not be able to, in the course of doing science, provide evidence for non-naturalistic hypotheses. Plantinga writes: 'I've argued that science doesn't conflict with Christian belief: can we go further, and say that science offers positive support for it?' He tries to argue that we can, by taking up the fine-tuning and biology-based design arguments - these arguments use scientific discoveries as premises for arguments for the existence of God. But if science is really committed to methodological naturalism, then these arguments automatically violate the methodology of science - we can only support naturalistic hypotheses in the course of doing science. (And moreover, using Simonian scientific claims as premises in arguments for theism is questionable, given that Christians have reason to question the truth of the scientific claims, since the scientific claims were arrived at subject to the limiting constraint of methodological naturalism.)

Plantinga and I both believe that this restriction on science is unwarranted though. Science can in principle provide evidence for the existence of God, and Plantinga gives an impressive and nuanced discussion of the extent to which the fine-tuning argument and biologybased design arguments do so. Science should not be restricted to following methodological naturalism.

Here's one reason why. If science really is committed to methodological naturalism, then it automatically follows that the aim of science is not generating true theories. Instead, the aim of science would be something like: generating the best theories that can be formulated subject to the restriction that those theories are naturalistic. More and more evidence could come in suggesting that a supernatural being exists, but scientific theories wouldn't be allowed to acknowledge that possibility. Imagine what might happen if the evidence becomes overwhelming - scientists might privately come to believe in the supernatural being, but scientific theories wouldn't be allowed to acknowledge that possibility. Long after overwhelming evidence has convinced everyone that the supernatural being exists, scientists would still be searching for naturalistic causes.

In this scenario, science would rightfully find itself a marginalized intellectual discipline. What would be the point of spending all the resources scientists have investigating natural causes, when it is evident 
that the causes are supernatural? I'm not saying that society would want to completely stop investigating the possibility of naturalistic causes, but by failing to countenance the possibility of supernatural hypotheses, scientists would be missing out on a revolution in our understanding of the world.

Thus, if evidence comes in against naturalism, investigation of the world that assumes naturalism has the potential to become otiose. Given the commitment to methodological naturalism, the success of science hinges on the contingent fact that naturalism is true. ${ }^{5}$

The lesson I draw from this is that scientists shouldn't build naturalism into the methodology of science. Imagine if they had done this sort of thing in the past; imagine if alchemy seemed to them like such a successful theory that they decided to follow methodological alchemism, the methodology that says that one should generate the best theories that can be formulated subject to the restriction that those theories are compatible with the fundamental principles of alchemy. Following such a methodology would have obviously impeded scientific progress.

Have scientists done something similar with naturalism? Plantinga says that they have, but I'm not convinced. Certainly, many scientists do say that they follow methodological naturalism. But I'm not convinced that they really mean it; I think they only follow methodological naturalism given their current perceived lack of evidence for alternative non-natural views. If evidence were to come in for non-naturalism, they would not exclude the non-natural interpretation of such evidence on methodological grounds. Or at least, they should not, and I'm confident that some scientists wouldn't. If the evidence for non-naturalism were strong enough, then the scientists who wouldn't exclude non-natural interpretations of the evidence would be the scientific revolutionaries, leading science from the old naturalistic paradigm to the new nonnaturalistic science that would eventually become normal science.

\section{ECUMENICAL SCIENCE}

Let's look in more detail at how this ecumenical science might go, where science is not restricted to the standard naturalistic methodology. As philosophers of science like Lakatos have spelled out, science can be viewed as a competition between research programmes. This can

${ }^{5}$ For more on this and related issues, see Bradley Monton, Seeking God in Science (Peterborough, ON: Broadview Press, 2009), Chapter 2. 
happen at a low level (e.g. different research programmes for how to best do spectroscopy), but it can also happen at a high level. Here are five competing high-level research programmes:

(1) Perennial naturalistic science - the standard naturalistic science as practiced in the $20^{\text {th }}$ century, excluding non-standard naturalistic alternatives such as the ones below. ${ }^{6}$

(2) Creative anti-realist science - science based on the view that 'we are actually responsible for the basic lineaments, the fundamental structure and framework of the world itself.7 This idea crops up in various places, such as in the interpretations of quantum mechanics that hold that observers create reality. ${ }^{8}$

(3) Christian science - the programme of doing science starting from what one believes as a Christian. (Plantinga also calls this 'Augustinian science.')

(4) Teleological science - the programme of looking at the world as having a fundamental teleological structure, but one that is not provided by any sort of supernatural agent. This is the research programme endorsed in Thomas Nagel's new book Mind and Cosmos. ${ }^{10}$ While technically naturalistic (Nagel does not endorse the existence of the supernatural), this is so different from standard naturalistic science that it constitutes a different highlevel research programme.

(5) Simulation science - the programme of looking at the universe that we observe as being a simulated universe. Some higher-level

${ }^{6}$ Note that this is not the same as Simonian science - Simonian science is characterized as science that produces theories incompatible with Christian belief, and while perennial naturalistic science may well do that, other types of science (such as the second highlevel research programme I list, creative anti-realist science) could do that too.

7 Alvin Plantinga, 'Christian Philosophy at the End of the 20th Century', in Sander Griffioen and Bert M. Balk (eds.), Christian Philosophy at the Close of the Twentieth Century, (Kampen: Kok, 1995), pp. 29-53 (p. 31).

${ }^{8}$ See for example the article about physicist John Wheeler's views by Tim Folger, 'Does the Universe Exist if We're Not Looking?', Discover Magazine, June 2002. Available at: <http://discovermagazine.com/2002/jun/featuniverse> [accessed 17/09/2013]. Especially pertinent in this context is the quote from prominent physicist Andre Linde: 'The universe and the observer exist as a pair. You can say that the universe is there only when there is an observer who can say, "Yes, I see the universe there." (From context it's clear that Linde is talking about naturalistic observers.)

9 Alvin Plantinga, 'Science: Augustinian or Duhemian?', Faith and Philosophy, 13 (1996), 368-394.

10 Thomas Nagel, Mind and Cosmos (Oxford: Oxford University Press, 2012). 
civilization is running a computer simulation of a universe, and the computer simulation is detailed enough that it simulates our brains, in a detailed enough way that it gives rise to our consciousness. Simulation science is compatible with naturalism (maybe the physical reality of the higher-level civilisation is all there is to reality), and with non-naturalism (maybe there is a God in the higher-level civilization, who may or may not care about simulated observers). ${ }^{11}$

These five are simply a representative sample of high-level research programmes one could follow. On my ecumenical view of science, all of these research programmes are legitimate ways of doing science. Thus, in response to Plantinga's excellent question of 'Shouldn't the Christian community engage in Christian science?', my answer is 'yes'. Moreover, this is my answer as an atheist; this is the answer that all atheists, and indeed all practitioners of science, should give.

Why is this the right answer? As I'll explain, there are three reasons: allowing for different scientists to follow different high-level research programmes encourages different avenues of inquiry; it opens up possibilities for interpreting data (which leads to new theory development); and it enables competing worldviews to be treated on a par on the scientific playing field.

I'll take these up in turn. First, allowing for competing highlevel research programmes encourages scientists to pursue different experimental areas of inquiry, areas of inquiry that those scientists who are following perennial naturalistic science might not contemplate. For example, a proponent of Simulation science would be especially interested in doing experiments to determine the values of the dimensionless fundamental constants, specifically how many significant digits they have. For example, if all dimensionless fundamental constants went out to 16 significant digits, with 0's as far as we could tell afterwards, this would provide some evidence that our universe is being generated via a base- 2 computer simulation. Proponents of perennial naturalistic science might put their experimental resources elsewhere - they might not be as interested in establishing the values of the dimensionless constants to as many significant digits as they can.

${ }^{11}$ For an argument that starts from certain not implausible premises, and concludes that we are probably living in a computer simulation, see Nick Bostrom, 'Are You Living in a Computer Simulation?', Philosophical Quarterly, 53 (2003), 243-255. 
Second, allowing for competing high-level research programmes opens up new possibilities for interpreting data - and, importantly, that leads to new avenues for theory development. For example, consider the new discovery that there is much less useless 'junk' DNA in the human genome than was previously thought. ${ }^{12}$ This can be taken to provide support for Christian science - arguably, God the designer wouldn't design us such that our genomes had useless parts. More importantly, though, this can lead to new theory development. People sometimes criticise intelligent design theory for not making new predictions, but in fact intelligent design proponents do make such predictions: for example, they predicted that so-called junk DNA would turn out to not be useless. ${ }^{13}$ But what some critics are looking for - at least, what I am looking for - are worked-out alternative theories that can compete with the existing perennial naturalistic ones. It's not easy to do, but having differing interpretations of the data is the first step toward providing these worked-out alternative theories. Such alternative theories will, hopefully, make empirical predictions at variance with the standard perennial naturalistic ones, and the predictions will, hopefully, be such that we have the ability to do empirical investigation to adjudicate which theory is empirically more accurate.

Third and finally, allowing for competing high-level research programmes enables competing worldviews to be treated on a par on the scientific playing field. Science is meant to be an objective endeavour that all people who strive to be rational can participate in. Being a Christian, as Plantinga has argued, may well be rational, and so science should not be done in such a way as to exclude Christianity. (And the same holds for the other high-level research programmes mentioned above.) As Plantinga rightly points out, if science is presented in such a way as to

${ }^{12}$ See, for example, Gina Kolata, 'Bits of Mystery DNA, Far From “Junk,” Play Crucial Role, The New York Times, September 5, 2012.

${ }^{13}$ See, for example, Jonathan Wells, The Myth of Junk DNA (Seattle: Discovery Institute Press, 2011). Other predictions include the predictions that the fundamental physical laws that describe the universe are simple and beautiful; that the fundamental physical laws are comprehensible to us; that we are in a location in the universe that is ideal for both survival and making observations to learn about the universe; that the universe had a beginning; that the biological realm is fundamentally good (that predators kill their prey quickly, for example); that many molecular machines are irreducibly complex; and that the prevalence of functional protein folds with respect to combinatorial sequence space will be extremely small. This list is purposefully varied from very general to very detailed, and could continue. 
exclude religious belief, this 'damages science ... because it forces many to choose between science and belief in God. ${ }^{14}$ One of the virtues of ecumenical science is that it treats competing worldviews on a par - the methodology of science does not privilege the naturalistic worldview over others. Thus, ecumenical science allows science to live up to the typical laudatory characteristics ascribed to it, that it's objective, open, and universal.

But even though I count all these high-level research programmes as scientific, my view is not 'anything goes'. In the next section, I'll discuss an important restriction on what arguments can be used within science to support these research programmes.

\section{FOR METHODOLOGICAL NEUTRALISM}

Suppose that Ric, a Christian, decides to do Christian science, and he decides to do Christian science by telling us about his sublime religious experiences he's had of the Christian God. Such testimony may well be accurate, and may well provide Ric - and us - warrant for believing that Christianity is true. But these are matters for philosophical debate, not scientific debate. In appealing to his religious experience, and principles in the epistemology of testimony, Ric is providing an argument for Christianity, but he's not providing a scientific argument for Christianity.

Contrast that with intelligent design proponents predicting that socalled 'junk' DNA is actually not useless, and then subsequent scientific investigation confirming that prediction. That is part of the standard methodology of science: one makes predictions that are either confirmed or disconfirmed by subsequent experiment.

I want to draw a line between these two sorts of cases. To do so, I endorse a principle I'm calling methodological neutralism. This principle can be understood as having two key components. First, when giving arguments for or against research programmes, one should not assume the truth of one particular research programme - the arguments should strive to be neutrally evaluable by proponents of any research programme. Second, the neutrally evaluable arguments one should give should be scientific arguments.

Of course, it would be nice if I had a characterization of what counts as a scientific argument. Philosophers have tried and failed to give

\footnotetext{
${ }^{14}$ Plantinga, Where the Conflict Really Lies, p. 54.
} 
such a characterization - the project of demarcating between science and non-science is fraught with difficulty, and its past is littered with failure, and that has led many philosophers of science to give up on the demarcation project. ${ }^{15}$ But that does not mean that a demarcation does not exist - Ric, in appealing to his religious experience, is not doing science, while the intelligent design proponents, in making a empirically testable prediction about junk DNA, are.

It's important to note that methodological neutralism does not place restrictions on belief, or reasons for belief. It's permissible to believe the worldview behind the high-level research programme one is following. ${ }^{16}$ Moreover, it's permissible to believe the worldview for non-scientific reasons: for example, one could believe the worldview because one has been convinced by a philosophical argument (rare though that may be).

The restrictions that methodological neutralism does place are on what arguments one puts forth to the tribunal of science. It's not within the realm of science to investigate historical arguments for Christianity, or Nagel's argument for teleological science, or Kant's argument for creative anti-realism, or Bostrom's argument for simulation science - or, for that matter, the philosophically-minded arguments that people like Dennett and Dawkins and Hitchens give in favour of naturalism. ${ }^{17}$

\section{CONCLUDING THOUGHTS}

I believe that Christian science is a degenerating research programme; Plantinga believes that it is a flourishing one. But this sort of conflict, in

${ }^{15}$ See, for example, Larry Laudan, 'The Demise of the Demarcation Problem', in R.S. Cohen and L. Laudan (eds.), Physics, Philosophy, and Psychoanalysis (Dordrecht: Reidel, 1983); reprinted in Michael Ruse (ed.) But is it Science? (Amherst, NY: Prometheus Books, 1988), pp. 337-350.

${ }^{16}$ Note that one can follow a research programme without having the corresponding belief in the truth of the worldview: one could accept the research programme, in the sense of committing to use it when doing science, without actually believing the worldview behind the programme. This distinction between acceptance and belief is famously made by Bas van Fraassen, The Scientific Image (Oxford: Oxford University Press, 1980).

${ }^{17}$ Here I have in mind, for example, the key argument against the existence of God presented in Richard Dawkins, The God Delusion (New York: Houghton Mifflin, 2006). The basic structure of Dawkins' argument is: the physical universe is complex, so anything that created the physical universe would have to be at least as complex, but the more complex some postulated being is the less likely it is to exist, so God is very unlikely to exist. Each step in this argument is a questionable philosophical step. 
principle, can be resolved on a scientific level. The evidence against junk DNA may well be an important piece of evidence in favour of Christian science. But the evidence that one can give a scientific, naturalistic account of why people are predisposed to form religious beliefs is, I maintain, undercutting evidence against Christian science. ${ }^{18}$ Those are just two examples of how the start of the debate could go.

But much more would need to be said. Why hasn't it? Well, science has developed a lot in the 20th century, but this development has mostly happened without the input of Christian science. The historical reasons for this are complex, but mirror to a large extent the reasons that Christian philosophy wasn't done during much of the 20th century Christian philosophers and Christian scientists kept their heads down, and did philosophy and science without taking into account what they believed as Christians. In philosophy, this situation famously changed in the latter part of the 20th century, thanks largely to the work of one Alvin Plantinga. By approaching philosophy starting from what he believes as a Christian, Plantinga has helped develop a philosophical research programme that can compete with other, naturalistic ones. Having such a competition is the best way for philosophy to flourish - this is a position on which both atheists and theists can (in principle) agree.

Just as Plantinga improved philosophy by doing Christian philosophy, so we need scientists to improve science by doing Christian science. We need people to be explicit that they are following that research programme, and to follow it where it leads. Plantinga admires the work of Michael Behe, even while disagreeing with the details, and I do too. But Behe and other intelligent design proponents often shy away from their Christian commitments, and from attributing particular characteristics to the nature of the intelligent designer they're postulating. ${ }^{19}$ There should be no need for them to do so. Let the Christian - and other highlevel - research programmes bloom, and the truth will out.

Or at least, letting these research programmes bloom is the best way to get at the truth from a scientific perspective (subject as it is to the

${ }^{18}$ For a brief presentation of my reasoning behind this, see Bradley Monton and Logan Paul Gage, Review of Plantinga's Where the Conflict Really Lies, International Journal for Philosophy of Religion, 72 (2012), 53-57.

19 Presumably, intelligent design proponents do not actually want their arguments to promote simulation science as much as they promote Christian science. By being more clear regarding the nature and workings of their hypothesized designer, they can avoid this undesired result. 
constraints of methodological neutralism). We can also do philosophy, and compare the competing research programmes in that discipline, and that will also help us to get at the truth. We can also reflect on our sinful natures, and on whether we have an innate faculty of perceiving divinity in the world that is corrupted by this sin. I maintain that Christian philosophy encompasses a false worldview, and that Christian science, even when it is further developed, will still be a degenerating research programme. But I recognize that, from a Christian perspective, in saying that I can see this, my sin remains. ${ }^{20}$

${ }^{20}$ For helpful comments, thanks to Brian Kierland and Ashley Taylor. 